\title{
Reconsidering sex-based stereotypes of COPD
}

\author{
*Jill Ohara, Leonard Fromerb, James F Donohue ${ }^{c}$ \\ a Section on Pulmonary, Critical Care, Allergy and Immunologic Diseases, Wake Forest University Health Sciences, Medical Center Boulevard, \\ Winston Salem, NC, USA \\ ${ }^{b}$ Department of Family Medicine, UCLA School of Medicine, Los Angeles, CA, USA \\ Division of Pulmonary Diseases and Critical Care Medicine, University of North Carolina School of Medicine, Chapel Hill, NC, USA
}

Originally submitted 7th October 2010; resubmitted 19th January 2011; revised 14th April 2011; accepted 7th May 2011;

online 16th September 2011

\begin{abstract}
Chronic obstructive pulmonary disease (COPD) has historically been considered a disease of older, white, male smokers, as illustrated in Frank Netter's classic images of the 'pink puffer' and 'blue bloater'. However, women may be more susceptible to COPD than men, and the disease course may be reflective of that increased susceptibility. From a review of epidemiological data of COPD, we found differences in the way men and women present with COPD symptoms, a bias in the way COPD symptoms are treated in men and women, and differences in susceptibility to airway obstruction based on age, sex, and smoking history. These data show that classic stereotypes of COPD - including male predominance - should be abandoned, and that there are not two but multiple COPD phenotypes, which are characterised by differences between women and men in susceptibility, symptoms, and disease progression. These differences impact on physician perception. Although further research into this concept is needed, the differences we found should prompt, in the short term, changes in the way (and in whom) COPD is evaluated, diagnosed, and treated; in the long term, these differences should prompt research into the prognosis of COPD based on sex differences.

(C) 2011 Primary Care Respiratory Society UK. All rights reserved.

J Ohar et al. Prim Care Respir J 2011; 20(4): 370-378

http://dx.doi.org/10.4104/pcrj.2011.00070
\end{abstract}

Keywords COPD, phenotypes, female, male, sex, gender, stereotypes

\section{Introduction}

Chronic obstructive pulmonary disease (COPD) is the fastest growing and fourth leading cause of death in the USA. ${ }^{1}$ Men and women present with COPD symptoms in very different ways. There is a bias against the diagnosis of COPD in women versus men, and there is growing evidence for differences in susceptibility to airway obstruction between men and women. We provide evidence that COPD may present as multiple phenotypes in both men and women, which extend beyond the scope of the classic Netter illustrations of the 'pink puffer' and 'blue bloater'. Awareness of this changing paradigm of COPD is important because COPD is most commonly diagnosed and managed by family physicians and generalists. The purpose of this review is to highlight new data that show that there are not two but multiple COPD phenotypes, characterised by differences between women and men in susceptibility, symptoms, and disease progression, and that these differences impact on physician perception.

\section{Methods}

A literature search was performed on PubMed, EMBASE, and Web of Science using the terms 'sex AND COPD', 'gender AND COPD', and 'female AND COPD', followed by a review of related articles based on references from the initial search. The review was limited to the English language literature.

\section{COPD redefined}

Only a minority of smokers (15-44\%) develop COPD, $, 2,3$ and individuals with COPD more frequently have cigarette-related comorbidities than controls without COPD matched for age, sex, and smoking status. ${ }^{4}$ These co-morbidities - which reflect the systemic nature of COPD - include cardiovascular disease,

\footnotetext{
* Corresponding author: Dr Jill Ohar, Section on Pulmonary, Critical Care, Allergy and Immunologic Disease, Wake Forest University Health Sciences, Medical Center Boulevard, Winston-Salem, North Carolina, 27157, USA.

Tel: +1 3367168426 Fax: +1 3367167277 E-mail: johar@wfubmc.edu
} 
peripheral vascular disease, systemic hypertension, and lung cancer. $^{5-9}$ Even non-cigarette-related conditions such as osteoporosis, depression, muscle wasting, cachexia, and the metabolic syndrome are more common in individuals with COPD than similarly matched smoking controls. ${ }^{10-14}$ The pattern of which and how many of these co-morbidities are present in an individual and the physiological and anatomical manifestations of these diseases all help to make up the 'phenotype', which is defined as the observable characteristics of an individual as determined both genetically and environmentally. The Netter illustrations of the 'pink puffer' and 'blue bloater' highlight emphysematous and bronchitic phenotypes of COPD - in older men. These should be viewed as anatomical and physiological elements of the various COPD phenotypes that have very different prevalences in men and women (see discussion of computed tomography patterns below). Other emerging COPD phenotypes highlight the systemic nature of this disease, which also affects men and women differently.

\section{Susceptibility}

Susceptibility is the capability of submitting to or inability to resist an action, process, operation, or risk factor. All of the following are considered to be risk factors for COPD: genes, inhalational exposure, lung growth and development, oxidative stress, infections, socioeconomic status, nutrition, and asthma. ${ }^{15}$ Sex is also a risk factor for COPD because there is an interaction between sex and many of the above-stated risk factors. ${ }^{15}$ First, sex affects genetic susceptibility. Silverman and colleagues found a markedly elevated prevalence of women $(71.4 \%)$ in a study of 84 probands with severe early-onset COPD. Furthermore, smoking female first-degree relatives of early-onset COPD probands were almost twice as likely to experience airway obstruction and 3.5 times more likely to have severe obstruction (forced expiratory volume in one second $\left.\left(\mathrm{FEV}_{1}\right)<40 \%\right)$ than male relatives who smoked. ${ }^{16}$ Sex also affects the type of COPD-provoking exposure. Women experience less first-hand but more second-hand tobacco smoke exposure than men. ${ }^{17}$ In developing countries where biomass fuels are used to heat homes and cook meals, women develop COPD more frequently from indoor air pollution than from cigarette exposure. ${ }^{15,18-21}$ Exposure to biomass fuels, occupational exposures, and remodelled asthma are important causal agents in the estimated $15 \%$ of individuals with COPD who have never smoked. ${ }^{22,23}$

Differences in lung growth rates between males and females combined with early age of smoking initiation ${ }^{24,25}$ and sex-specific smoking behaviours ${ }^{26,27}$ further enhance the susceptibility of women to tobacco smoke. Girls have an earlier and more accelerated lung growth than boys but, at adulthood, women have smaller lungs than men. ${ }^{28}$ Age-related loss of elastic recoil occurs later in women. ${ }^{28}$ In a UK study, smoking initiation at an early age ( $<16$ years) was associated with a lower $\mathrm{FEV}_{1}$ in both male and female current smokers and ex-smokers; however, this effect was most apparent in female current smokers. ${ }^{24}$ Similarly, Gold and co-workers showed that early exposure to as few as five cigarettes/day resulted in a fivefold greater reduction in lung growth rate in girls than in boys. ${ }^{29}$ Women have a lower socioeconomic status than men in many countries, which can affect nutrition and frequency of respiratory tract infections. ${ }^{30}$ Sex hormones have also been shown to modulate oxidative stress and aging ${ }^{31,32}$ and alveolar regeneration. ${ }^{33}$

Epidemiological data regarding enhanced susceptibility of women over men to COPD is mixed, but generally compelling. Methodological differences in studies that may be responsible for these inconsistencies include:

(1) Failure to compensate for cigarette consumption. Women tend to smoke fewer cigarettes and to have different smoking patterns from men. Women more commonly smoke both filtered and mentholated cigarettes. ${ }^{34}$ They generally smoke fewer cigarettes per day, and urinary cotinine levels (corrected for the number of cigarettes smoked) are lower in women. ${ }^{34}$ However, Leynaert and co-workers have suggested that the smaller airways in women may expose their lungs to a greater dose of smoke/cigarette than men. ${ }^{35}$

(2) Exclusion of subjects who display bronchial hyperreactivity (BHR). Women with COPD are more likely to have BHR than men. ${ }^{35-38} \mathrm{BHR}$ is a predictor of COPD severity because it is indicative of both the rate of progression of COPD and death due to the disease. . $^{36,39,40}$

(3) Measurement of susceptibility by annual decline of FEV 1 in $\mathrm{mL}$ rather than in percent predicted $\mathrm{FEV}_{1}$ or lower limit of normal. Because women have, in general, smaller body size than men, their annual decline in $\mathrm{FEV}_{1}$, as measured in $\mathrm{mL}$, would underestimate their true loss of lung function.

Evidence for enhanced susceptibility of women for COPD includes studies that show an increased rate of decline in $\mathrm{FEV}_{1}$ in women compared with men ${ }^{25,41-46}$ and an increased rate of COPD-related events. ${ }^{1}$ A recent systematic review and metaanalysis of 11 population-based cohort studies showed that the annual decline in percentage predicted $\mathrm{FEV}_{1}$ was greater for women than for men. ${ }^{46} \mathrm{~A}$ case-control study of patients with stable COPD attending a pulmonary clinic in Spain showed that women, when matched with men for percent predicted $\mathrm{FEV}_{1}$, were younger $(48 \pm 28$ vs. $65 \pm 8$ years, $p=0.001)$, smoked less ( $48 \pm 28$ vs. $69 \pm 27$ pack-years, $p=0.001)$, had more exacerbations in the previous year ( 1 vs. $0, p=0.009$ ), and performed worse on the 6 -minute walking distance test $(87 \pm 18$ vs. $105 \pm 22$ percentage predicted, $\mathrm{p}=0.001 ; 444 \pm 85$ vs. $518 \pm 92$ metres, $\mathrm{p}=0.001)$ than men. ${ }^{47}$ In another study, women started smoking at an older age (17 vs. 15 years, $p<0.001$ ) and had fewer packyears of smoking (20.5 vs. 38.3, $p<0.001)$ than men with comparable percent predicted FEV 1 (81.5\% females vs. $79.2 \%$ 
males, $\mathrm{p}=0.279){ }^{45}$ Finally, a long-term study of smokers in the Netherlands suggested that $\mathrm{FEV}_{1}$ declined more rapidly in women smokers than in men who smoked. ${ }^{42-44}$

The cause of increased susceptibility in women is unknown. The most obvious factor would be oestrogen-related, and several studies have shown that post-menopausal women who use hormone replacement therapy (HRT) experience less pulmonary function decline and less inflammation than older women who do not take exogenous hormones. ${ }^{31,48.50}$ In the Cardiovascular Health Study, spirometry was performed on 2,353 women older than 65 years who could provide information on HRT use. FEV 1 was higher overall in women who were currently using HRT than in those who were not currently using HRT (1.82 L vs. $1.66 \mathrm{~L}, \mathrm{p}<0.0001)$, including former smokers (currently using versus not currently using HRT: $1.76 \mathrm{~L}$ vs. $1.60 \mathrm{~L}, \mathrm{p}=0.013)$ and never smokers $(1.90 \mathrm{~L}$ vs. $1.72 \mathrm{~L}$, $\mathrm{p}<0.0001)$. Overall, HRT users were also $25 \%$ less likely to have airways obstruction than women not currently using HRT. ${ }^{31}$ Similar findings were also seen in a small study $(\mathrm{N}=85)$ in which women who used HRT were $88 \%$ less likely to have BHR than non-HRT users, although mild BHR showed no association with HRT use. ${ }^{49}$ However, the relationship of sex hormones to COPD is probably complex, given that women appear as a group to be more susceptible to COPD than men. Clearly, more research is needed on the link between oestrogen and susceptibility.

Increased susceptibility should translate into increased prevalence. However, few studies show a greater prevalence of COPD in women than in men. This is probably related to the presence of the same methodological biases that plague susceptibility studies, and the fact that insufficient time had elapsed to show the effects of enhanced susceptibility on prevalence. For example, in the National Population Health Study of Canada, the prevalence of COPD was higher in women overall $(8.2 \%$ vs. $3.5 \%)$ and in female non-smokers $(2.1 \%$ vs. $0.8 \%)$, but equivalent between the sexes in smokers $(2.7 \%$ women vs. $2.8 \%$ men). ${ }^{51}$ In current smokers the prevalence of COPD was $10.1 \%$ in women compared with $3.8 \%$ in men who started smoking before age 18 . The age at which women started smoking had a dramatic effect on the prevalence of COPD compared with men. For those who started smoking after age 18 (and were current smokers), COPD prevalence was still twice as high in women as in men (5.9\% vs. $3.0 \%)$. In ex-smokers there was no difference in the prevalence of COPD between the sexes..$^{51}$ In contrast, De Torres and co-workers found that the prevalence of COPD was higher in men than in women $(30.5 \%$ vs. $22.3 \%, p<0.001)$ with similar degrees of obstruction (FEV 1 $78 \%$ of predicted in men and $75 \%$ of predicted in women) and irrespective of the pack-year smoking history. However, in this study, persons with a positive bronchodilator response were excluded..$^{52} \mathrm{~A} 25$-year follow-up study of the general population in Copenhagen showed no difference in COPD prevalence between men and women; however, the authors noted that classification of smoking history was not detailed. Because men smoked more tobacco daily than women at that time in Denmark, a higher susceptibility of women to COPD per gram of tobacco may have been masked. The higher risk for women in this study was only discovered when tobacco consumption was measured in detail..$^{53}$ An Austrian study showed that COPD was as common in women as in men but, when compared across age groups, it was more common in women in the 40-49-year age group. ${ }^{54}$ In studies using self-report for calculation of prevalence values the results are also mixed. The National Health Interview Study found a greater number of women than men (7.2 vs. 4.4 cases/million) with chronic bronchitis and emphysema. By contrast, in the National Health and Nutritional Examination Study (NHANES) there were 74.3 vs. 58.2 selfreported cases of COPD per 1,000 men and women, respectively. A recent meta-analysis of 62 population-based studies from 1990 to 2004 showed a prevalence of 2:1 in men versus women for COPD. ${ }^{55}$

\section{Symptoms}

Women present with COPD differently from men. Female COPD patients report a higher level of dyspnoea for the same level of ventilatory impairment than men. ${ }^{56,57}$ In the Confronting COPD International Survey, women were more likely to report severe dyspnoea than men (odds ratio (OR) $1.30,1.10-1.54)$, with similar cough (OR 1.08, 0.92-1.27) and less sputum (OR 0.84, 0.72-0.98), despite significantly lower pack-years of smoking (mean (SD) 36 (29) vs. 46 (35) pack-years). ${ }^{58}$ Women enrolled in the National Emphysema Treatment Trial (NETT) also experienced greater dyspnoea and lower quality of life than men matched for precent predicted $\mathrm{FEV}_{1}$, age, proportion of the lung affected by emphysema, and pack-years. ${ }^{59}$ Two studies by De Torres and co-workers have similarly shown differences between men and women with regard to reporting of sputum and dyspnoea. ${ }^{47,52}$ Women with COPD tend to report more cough than men but less sputum; however, this may be a cultural/societal artefact as women tend to swallow phlegm and may be less likely to admit to having it. ${ }^{45}$ Regardless of whether the increased reporting of dyspnoea with reduced reporting of sputum among women compared with men is related to patient perception or reality, knowledge of this difference is important when formulating a differential diagnosis. Contrary to the above, Watson and colleagues found similar reporting of symptoms between the sexes in the 816 men and 312 women enrolled in the EUROSCOP Study. ${ }^{60}$ In this study, as with the other reports noted above, men but not women reported an improvement in symptoms with treatmentinduced improvement in $\mathrm{FEV}_{1}$.

Overall, women with COPD have a lower health-related 
quality of life (HRQL) corrected for $\mathrm{FEV}_{1}$. In a recent study evaluating HRQL in outpatients with COPD $(1,786$ women and 1,661 men), women showed significantly lower scores in all physical and mental domains of the HRQoL measures (SF12) than men. The physical component of the SF-12 was especially impaired in women compared with men of the same age and severity of COPD. ${ }^{61}$

\section{Co-morbidities}

Women tend to experience more co-morbidities and of a different pattern than men. Depression and anxiety are common COPD co-morbidities that affect the hospitalisation rate and quality of life. ${ }^{56,62}$ Women with COPD suffer more from depression and have a lower quality of life than men. ${ }^{47,5,59,59,63-67}$ Women also appear to employ different coping strategies for COPD than men. ${ }^{68}$

Airflow obstruction is associated with a 4-5-fold increase in lung cancer when all other risk factors are controlled. ${ }^{57,69}$ Although lung cancer is more common in smokers with airflow obstruction than those without, women may be more susceptible to smoking-related lung cancer than men. ${ }^{70-73}$

Osteoporosis, which is typically thought of as a disease of Caucasian women, has a higher prevalence among smokers with airflow obstruction regardless of sex. Sin and co-workers have shown that the severity of osteoporosis can be linked to the severity of COPD measured by FEV $1 .{ }^{11}$ This association between COPD severity and osteoporosis severity is probably related to bone mineral metabolism abnormalities found in smokers, ${ }^{74}$ premature menopause in women smokers, use of systemic steroids for COPD exacerbations, and inactivity related to COPD-associated exercise limitation.

\section{Diagnosis \\ Diagnostic testing}

Data from the NETT, the National Lung Screening Trial, and the GlaxoSmith Kline International COPD Genetics Network all show that women have less emphysema than men; however, based on computed tomography scanning, airway thickness appears to be increased in women. ${ }^{32,59,75}$ While other studies have confirmed these findings, recent data suggest that the progression of emphysema with age is increased in women compared with men. ${ }^{76}$ Another recent study showed that airway thickness and the percentage of emphysema are dependent upon age and smoking status. ${ }^{77}$ In contrast to other studies noted above, this study shows that there are more cases of emphysema in men than in women, and airway thickness was increased in men compared with women.

Also in the NETT, women had lower carbon monoxide diffusion capacity and oxygen pressure, higher carbon dioxide pressure, shorter 6-minute walk distance, and lower maximal wattage during oxygen-supplemented cycle ergometry than men despite less severe airways obstruction. ${ }^{59}$ Women also experienced a higher BODE index (body mass index/airflow obstruction measured by $\mathrm{FEV}_{1} /$ dyspnoea measured on a modified British Medical Research scale/exercise capacity measured by 6-minute walk test) for a given percent predicted $\mathrm{FEV}_{1}$, age, number of pack-years, and proportion of emphysema than men. ${ }^{59}$ Other studies have confirmed these physiological differences between women and men with COPD. ${ }^{47,52,76}$

\section{Diagnostic bias}

COPD may be diagnosed less frequently in women than in men perhaps because of a bias against recognising COPD symptoms (and therefore pursuing a diagnosis) in women compared with men. COPD is currently defined as an $\mathrm{FEV}_{1} /$ forced vital capacity (FVC) $<70 \%$ and is diagnosed based on both clinical history of COPD symptoms (cough, wheeze, sputum, and dyspnoea upon exertion) with confirmation of obstruction on spirometry. ${ }^{15}$ As noted, the pattern of symptoms reported by women is different than for men, which may result in less spirometric testing in women than in men. Watson and co-workers showed that women who presented with signs or symptoms of COPD were less likely to have spirometric testing than men (OR $0.84,95 \% \mathrm{Cl} 0.72$ to 0.98 ) but, ironically, were more likely to get smoking cessation advice than men (OR $1.57,95 \% \mathrm{Cl} 1.33$ to 1.86$).{ }^{58}$ Further illustrative of the bias in diagnosing COPD in women is a study of Canadian and American primary care physicians using a hypothetical case presentation of cough and dyspnoea in a smoker, presented in six versions differing only in the age and sex of the patient. After presentation of the history and physical findings, the physicians were asked to state the most probable diagnosis and to choose the diagnostic studies needed. The physicians were then presented with spirometric findings of moderate or severe obstruction without significant bronchodilator response and again asked for a provisional diagnosis. They were finally told of a negative outcome of an oral steroid trial. Initially, COPD was given as the most probable diagnosis significantly more often for the male than for the female case presentations. In this study the physicians more often diagnosed the women (incorrectly) as having asthma. These initial significant sex-based differences decreased as objective information from spirometry was provided. Unfortunately, only $21.8 \%$ of the study physicians would have requested spirometry after the initial presentation. ${ }^{78}$ In a similar study in Spain, COPD was more likely to be the preliminary diagnosis for male patients than for female patients (OR 1.55, 95\% Cl 1.15 to 2.1 ), but the sex bias disappeared once the physicians were shown spirometry results. ${ }^{79}$ This apparent bias may be fading, however, as a more recent study involving five US health plans that covered 1.6 million members showed that women smokers were slightly more likely than men to undergo spirometry (33\% vs. $29.4 \%$, 
$\mathrm{p}=0.001){ }^{80}$ However, a diagnostic bias still remains in selfreport as illustrated by an emergency department study that found women more commonly reported a mixed diagnosis of asthma and COPD than men ( $48 \%$ vs. $39 \%$ ) when presenting with an exacerbation of obstructive lung disease. ${ }^{81}$

\section{Treatment Smoking cessation}

Women are generally less successful at long-term smoking abstinence than men. ${ }^{38,82,83}$ Women tend to anticipate more barriers to smoking cessation, ${ }^{84}$ to experience greater depression with a smoking cessation attempt, ${ }^{84}$ and have higher behavioural but lower nicotine dependence. ${ }^{83}$ These tendencies may explain why women appear to benefit from exercise as an aid to smoking cessation and men do not. ${ }^{85}$ While both bupropion ${ }^{86}$ and varenicline $e^{87,88}$ have equal efficacy in women and men, women are less successful at achieving sustained smoking abstinence with nicotine replacement therapy than men. .9990 The difference in efficacy of nicotine replacement therapy between men and women may be related to the relatively flat nicotine response curve of women compared with men, ${ }^{89}$ or may be due to women's accelerated rate of metabolism of nicotine compared with men. ${ }^{91}$

\section{Bronchodilating agents}

Bronchodilators are the mainstay of pharmacotherapy for COPD. ${ }^{15,92}$ Long-acting bronchodilating agents are recommended as maintenance therapy for GOLD stage 2 and above (post-bronchodilator $\mathrm{FEV}_{1}<80 \%$ predicted) and shortacting bronchodilating agents are used on an as-needed basis at every GOLD stage. While response to the short-acting $\beta_{2}-$ agonist albuterol is significantly greater in men than in women when measured in $\mathrm{mL}$, when measured in percent predicted FEV 1 this difference is lost..$^{93}$ Similarly, the bronchodilating response to the short-acting anticholinergic ipratropium bromide and long-acting bronchodilators tiotropium and salmeterol is equivalent in men and women (data on file, Boehringer-Ingelheim). More recent analysis of the dataset from the UPLIFT trial (a study evaluating the effects of tiotropium on rate of decline in $\mathrm{FEV}_{1}$ in 5,992 patients, $75 \%$ men, $25 \%$ women) showed that women with COPD were younger than the men and were more commonly current smokers but had fewer pack-years. Rates of decline in both preand post-bronchodilator FEV 1 and FVC were slightly lower for women than for men in absolute terms, but similar when expressed as the yearly decline in percent predicted (co-primary endpoints). Similarly, hazard ratios (HR) for first exacerbation (tiotropium/placebo) were similar in men and women (0.87, 95\% Cl 0.81 to 0.93 for men and $0.83,95 \% \mathrm{Cl} 0.74$ to 0.94 for women). Exacerbations requiring hospitalisations (a secondary endpoint) declined in both, but to a greater extent in women (HR 0.77, 95\% Cl 0.62 to 0.94) than men (HR 0.89,
$95 \% \mathrm{Cl} 0.79$ to 0.99 ). Women had worse baseline HRQoL as measured by the St George's Respiratory Questionnaire, but both men and women improved to the same extent. Improvement in survival was similar. ${ }^{94}$

For GOLD stage $\geq 3$, combination therapy including an inhaled corticosteroid is recommended. Bronchodilator effect and the effect on disease modification endpoints such as exacerbation frequency, rate of decline in $\mathrm{FEV}_{1}$, and mortality for an inhaled corticosteroid coupled with the long-acting bronchodilators salmeterol or formoterol are also equivalent in men and women. ${ }^{95-100}$

\section{Pulmonary rehabilitation}

Women tend to complain of more dyspnoea than men for a given decrement in $\mathrm{FEV}_{1}$. Despite this seeming impediment to physical rehabilitation, sex does not influence pulmonary rehabilitation outcomes even in severely dyspnoeic subjects. ${ }^{101,102}$ However, when short (3 months) versus long (18 months) duration pulmonary rehabilitation was compared in men and women, only men experienced continued benefit in HRQL after 3 months of therapy. ${ }^{103}$

\section{Supplemental oxygen}

While women appear to be more susceptible to hypoxaemia than men, hypoxaemia has a less detrimental effect on survival in women than in men. A study of Swedish COPD patients receiving oxygen therapy showed that the annual incidence and prevalence of starting oxygen therapy increased more rapidly in women than in men, yet survival was better in women with long-term oxygen therapy than in men: median (first and third quartile) survival was 2.8 (2.6-2.9) years in women vs. 2.0 (1.9 to 2.1$)$ years in men with a relative risk for death of 1.21 (95\% Cl 1.14 to 1.28). ${ }^{104}$ In another study the HR for death in men versus women on supplemental oxygen was $1.54(95 \% \mathrm{Cl} 1.15$ to 2.07$){ }^{105}$

\section{Prognosis}

Data from the National Vital Statistics analysed by the Centers for Disease Control and Prevention show that, during the years 2000-2005, the annual death rate from COPD increased by $5 \%$ annually for men and $11 \%$ for women, further widening the gap in mortality between women and men. ${ }^{106}$ Hospitalisation for COPD increased in women by $43 \%$ and in men by $12 \%$ over the interval $1980-2000$. Women with COPD are more likely to be hospitalised for COPD and to die from it than men, even when adjusting for smoking history. ${ }^{44,107}$ In one study the increased relative risk for women ranged from 1.5 (95\% Cl 1.2 to 2.1 ) to $3.6(95 \% \mathrm{Cl} 1.4$ to 9.0$) .{ }^{44}$ However, in another study, when men and women were matched by BODE index, survival was significantly better for women. ${ }^{108}$ Women also appear to be at increased risk of death from COPD-related co-morbidities. ${ }^{109}$ Swedish census data show that female smokers display slightly higher relative death rates from 
ischaemic heart disease when the effect of the amount of cigarette consumption is considered. ${ }^{110}$

\section{Conclusions}

Although this study is not a formal meta-analysis, this review of epidemiological and clinical data indicates that the paradigm of COPD is changing from a male-predominant two-category disease to a disorder characterised by multiple co-morbidities with a growing female prevalence. Dyspnoea on exertion, wheeze, and cough with sputum are the cardinal symptoms of COPD. Yet women seem to over-report dyspnoea and underreport sputum production compared with men. Doctors tend to underutilise spirometry relative to the frequency of patient reports of symptoms. Therefore, an important first step towards addressing any sex differences in COPD and for better overall management of COPD is for physicians actively to solicit the report of respiratory complaints in smokers and to perform spirometry when symptoms are present. Although further research into this concept is needed, physicians also need to realise that women's complaints related to COPD are different from men's, and the disease course in women is different (increased susceptibility, faster rate of $\mathrm{FEV}_{1}$ decline, more hospitalisations, more dyspnoea, more deaths from COPD).

\section{Handling editor}

Onno van Schayck

\section{Acknowledgements}

The authors acknowledge the editorial assistance of Mary Gabb, MS, from American Healthcare Communications, whose services were provided by BoehringerIngelheim Inc (BI) and Pfizer Inc. Responsibility for the content rests with the authors who originated and developed the intellectual content and performed substantive scientific revisions. The manuscript was developed from presentations and discussions at a taskforce meeting, 'Clinical Implications of Diagnosis and Treatment of COPD', which took place in Jacksonville, Florida on 13-14 March 2008.

\section{Conflicts of interest}

Dr Ohar is not a consultant nor does she have research contracts. Dr Fromer, Speakers Bureau for $\mathrm{BI}$ and Pfizer. Dr Donohue is a consultant for $\mathrm{BI}$. He receives honoraria for lectures and has reseach contracts between $\mathrm{BI}$ and UNC that he is the principal investigator.

\section{Contributorship}

Dr Ohar performed the research and literature search, wrote the first draft, and led the manuscript review process. Dr Fromer served as a co-author and provided original content as well as editorial review of the content of this paper. Dr Donohue participated in the writing, research and literature search as well as the manuscript review process.

\section{Funding}

The meeting, authors' participation and manuscript preparation were supported by $\mathrm{BI}$ and Pfizer. BI and Pfizer did not review or edit the manuscript except to check it for medical misrepresentation.

\section{References}

1. Mannino DM, Homa DM, Akinbami LF, Ford ES, Redd SC. Chronic obstructive pulmonary disease surveillance--United States, 1971-2000. MMWR Surveill Summ 2002;51(6):1-16.

2. Ohar JA, Sadeghnejad A, Donohue J, Meyers DA, Bleecker ER. Do symptoms predict COPD in smokers? Chest 2010;137(6):1345-53. http://dx.doi.org/ 10.1378/chest.09-2681

3. Rennard SI, Vestbo J. COPD: the dangerous underestimate of $15 \%$. Lancet 2006;367(9518):1216-19. http://dx.doi.org/10.1016/S0140-6736(06)68516-4

4. Holguin F, Folch E, Redd SC, Mannino DM. Comorbidity and mortality in COPDrelated hospitalizations in the United States, 1979 to 2001. Chest 2005;128(4):2005-11. http://dx.doi.org/10.1378/chest.128.4.2005

5. Tockman MS, Anthonisen NR, Wright EC, Donithan MG. Airway obstruction and the risk for lung cancer. Ann Intern Med 1987;106(4):512-18.

6. Nomura A, Stemmermann GN, Chyou P-H, Marcus EB, Buist AS. Prospective study of pulmonary function and lung cancer. Am Rev Respir Dis 1991;144(2):307-11.

7. Islam SS, Schottenfeld D. Declining FEV1 and chronic productive cough in cigarette smokers: a 25-year prospective study of lung cancer incidence in Tecumseh, Michigan. Cancer Epidemiol Biomarkers Prev 1994;3(4):289-95.

8. Mapel DW, Dedrick D, Davis K. Trends and cardiovascular co-morbidities of COPD patients in the Veterans Administration Medical System, 1991-1999. COPD 2005;2(1):35-41. http://dx.doi.org/10.1081/COPD-200050671

9. Turner MC, Chen Y, Krewski D, Calle EE, Thun MJ. Chronic obstructive pulmonary disease is associated with lung cancer mortality in a prospective study of never smokers. Am J Respir Crit Care Med 2007;176(3):285-90. http://dx.doi.org/10.1164/rccm.200612-17920C

10. Lazarus R, Sparrow D, Weiss ST. Baseline ventilatory function predicts the development of higher levels of fasting insulin and fasting insulin resistance index: the Normative Aging Study. Eur Respir J 1998;12(3):641-5. http://dx.doi.org/10.1183/09031936.98.12030641

11. Sin DD, Man JP, Man SF. The risk of osteoporosis in Caucasian men and women with obstructive airways disease. Am J Med 2003;114(1):10-14. http://dx.doi.org/10.1016/S0002-9343(02)01297-4

12. Jorgensen NR, Schwarz P, Holme I, Henriksen BM, Petersen L, Backer V. The prevalence of osteoporosis in patients with chronic obstructive pulmonary disease: a cross sectional study. Respir Med 2007;101(1):177-85. http://dx.doi.org/10.1016/j.rmed.2006.03.029

13. Chatila WM, Thomashow BM, Minai OA, Criner GJ, Make BJ. Comoribidites in chronic obstructive pulmonary disease. Proc Am Thorac Soc 2008;5(4):549-55 http://dx.doi.org/10.1513/pats.200709-148ET

14. Agusti A, Soriano JB. COPD as a systemic disease. COPD 2008;5(2):133-8. http://dx.doi.org/10.1080/15412550801941349

15. Global Initiative for Chronic Obstructive Lung Disease. Global Strategy for the Diagnosis, Management, and Prevention of Chronic Obstructive Pulmonary Disease, Updated 2007. Available at: www.goldcopd.org (accessed 7 May 2008).

16. Silverman EK, Weiss ST, Drazen JM, et al. Gender-related differences in severe, early-onset chronic obstructive pulmonary disease. Am J Respir Crit Care Med 2000;162(6):2152-8.

17. U.S. Department of Health and Human Services. The Health Consequences of Involuntary Exposure to Tobacco Smoke: A Report of the Surgeon GeneralExecutive Summary. U.S. Department of Health and Human Services, Centers for Disease Control and Prevention, Coordinating Center for Health Promotion, National Center for Chronic Disease Prevention and Health Promotion, Office on Smoking and Health, 2006.

18. Varkey $A B$. Chronic obstructive pulmonary disease in women: exploring gender differences. Curr Opin Pulm Med 2004;10(2):98-103. http://dx.doi.org/ 10.1097/00063198-200403000-00003

19. Schwela D. Cooking smoke: a silent killer. People Planet 1997;6(3):24-5.

20. Pérez-Padilla R, Regalado J, Vedal $S$, et al. Exposure to biomass smoke and chronic airway disease in Mexican women. A case-control study. Am J Respir Crit Care Med 1996;154(3 Pt 1):701-6

21. Liu S, Zhou $Y$, Wang $X$, et al. Biomass fuels are the probable risk factor for chronic obstructive pulmonary disease in rural South China. Thorax 2007;62(10):889-97. http://dx.doi.org/10.1136/thx.2006.061457

22. Coultas DB, Mapel D, Gagnon R, Lydick E. The health impact of undiagnosed 
airflow obstruction in a national sample of United States adults. Am J Respir Crit Care Med 2001;164(3):372-7.

23. Birring SS, Brightling CE, Bradding $P$, et al. Clinical, radiologic, and induced sputum features of chronic obstructive pulmonary disease in nonsmokers: a descriptive study. Am J Respir Crit Care Med 2002;166(8):1078-83. http://dx.doi.org/10.1164/rccm.200203-2450C

24. Patel $B D$, Luben $R N$, Welch $A A$, et al. Childhood smoking is an independent risk factor for obstructive airways disease in women. Thorax 2004;59(8):682-6. http://dx.doi.org/10.1136/thx.2003.010215

25. Langhammer A, Johnsen R, Gulsvik A, Holmen TL, Bjermer L. Sex differences in lung vulnerability to tobacco smoking. Eur Respir J 2003;21(6):1017-23. http://dx.doi.org/10.1183/09031936.03.00053202

26. Mustonen TK, Spencer SM, Hoskinson RA, Sachs DP, Garvey AJ. The influence of gender, race, and menthol content on tobacco exposure measures. Nicotine Tob Res 2005;7(4):581-90. http://dx.doi.org/10.1080/14622200500185199

27. Thun MJ, Lally CA, Flannery JT, Calle EE, Flanders WD, Heath CW Jr. Cigarette smoking and changes in the histopathology of lung cancer. J Natl Cancer Inst 1997;89(21):1580-6. http://dx.doi.org/10.1093/jnci/89.21.1580

28. Becklake MR, Kauffman F. Gender differences in airway behaviour over the human life span. Thorax 1999;54(12):1119-38. http://dx.doi.org/ 10.1136/thx.54.12.1119

29. Gold DR, Wang X, Wypij D, Speizer FE, Ware JH, Dockery DW. Effects of cigarette smoking on lung function in adolescent boys and girls. N Engl J Med 1996;335(13):931-7. http://dx.doi.org/10.1056/NEJM199609263351304

30. Koster A, Bosma H, van Lenthe FJ, Kempen Gl, Mackenbach JP, van Eijk JT. The role of psychosocial factors in explaining socio-economic differences in mobility decline in a chronically ill population: results from the GLOBE study. Soc Sci Med 2005;61(1):123-32. http://dx.doi.org/10.1016/j.socscimed.2004.11.045

31. Carlson CL, Cushman M, Enright PL, Cauley JA, Newman AB. Hormone replacement therapy is associated with higher FEV1 in elderly women. Am J Respir Crit Care Med 2001;163(2):423-8.

32. Dransfield MT, Davis JJ, Gerald LB, Bailey WC. Racial and gender differences in susceptibility to tobacco smoke among patients with chronic obstructive pulmonary disease. Respir Med 2006;100(6):1110-16. http://dx.doi.org/10.1016/ j.rmed.2005.09.019

33. Massaro D, Massaro GD. Toward therapeutic pulmonary alveolar regeneration in humans. Proc Am Thorac Soc 2006;3(8):709-12. http://dx.doi.org/10.1513/ pats.200605-127SF

34. Gan WQ, Cohen SB, Man SF, Sin DD. Sex-related differences in serum cotinine concentrations in daily cigarette smokers. Nicotine Tob Res 2008;10(8):1293-300. http://dx.doi.org/10.1080/14622200802239132

35. Leynaert B, Bousquet J, Henry C, Liard R, Neukirch F. Is bronchial hyperresponsiveness more frequent in women than in men? A population-based study. Am J Respir Crit Care Med 1997;156(5):1413-20.

36. Kanner RE, Connett JE, Altose MD, et al. Gender difference in airway hyperresponsiveness in smokers with mild COPD. The Lung Health Study. Am J Respir Crit Care Med 1994;150(4):956-61.

37. Paoletti P, Carrozzi L, Viegi G, et al. Distribution of bronchial responsiveness in a general population: effect of sex, age, smoking, and level of pulmonary function. Am J Respir Crit Care Med 1995;151(6):1770-7.

38. Connett JE, Murray RP, Buist AS, et al. Changes in smoking status affect women more than men: results of the Lung Health Study. Am J Epidemiol 2003;157(11):973-9. http://dx.doi.org/10.1093/aje/kwg083

39. Tashkin DP, Altose MD, Connett JE, Kanner RE, Lee WW, Wise RA. Methacholine reactivity predicts changes in lung function over time in smokers with early chronic obstructive pulmonary disease. Am J Respir Crit Care Med 1996;153(6 Pt 1):1802-11.

40. Hospers JJ, Postma DS, Rijcken B, Weiss ST, Schouten JP. Histamine airway hyperresponsiveness and mortality from chronic obstructive pulmonary disease: a cohort study. Lancet 2000;356(9238):1313-17. http://dx.doi.org/10.1016/S01406736(00)02815-4
41. Chen $Y$, Horne SL, Dosman JA. Increased susceptibility to lung dysfunction in female smokers. Am Rev Respir Dis 1991;143(6):1224-30.

42. Xu X, Weiss ST, Rijcken B, Schouten JP. Smoking, changes in smoking habits, and rate of decline in FEV1: new insight into gender differences. Eur Respir $J$ 1994;7(6):1056-61

43. Xu X, Li B, Wang L. ender difference in smoking effects on adult pulmonary function. Eur Respir J 1994;7(3):477-83. http://dx.doi.org/ 10.1183/09031936.94.07030477

44. Prescott E, Bjerg AM, Andersen PK, Lange P, Vestbo J. Gender differences in smoking effects on lung function and risk of hospitalization for COPD: results from a Danish longitudinal population study. Eur Respir J 1997;10(4):822-7.

45. Watson L, Vonk JM, Lofdahl CG, et al. Predictors of lung function and its decline in mild to moderate COPD in association with gender: results from the EUROSCOP study. Respir Med 2006;100(4):746-53. http://dx.doi.org/10.1016/ j.rmed.2005.08.004

46. Gan WQ, Man SF, Postma DS, Camp P, Sin D. Female smokers beyond the perimenopausal period are at increased risk of chronic obstructive pulmonary disease: a systematic review and meta-analysis. Respir Res 2006;7:52. http://dx.doi.org/ 10.1186/1465-9921-7-52

47. De Torres JP, Casanova C, Hernandez C, Abreu J, Aguirre-Jaime A, Celli BR. Gender and COPD in patients attending a pulmonary clinic. Chest 2005;128(4):2012-6. http://dx.doi.org/10.1378/chest.128.4.2012

48. Pata O, Atis S, Utku Oz A, et al. The effects of hormone replacement therapy type on pulmonary functions in postmenopausal women. Maturitas 2003;46(3):213-18. http://dx.doi.org/10.1016/S0378-5122(03)00191-9

49. Mueller JE, Frye C, Brasche S, Heinrich J. Association of hormone replacement therapy with bronchial hyper-responsiveness. Respir Med 2003;97(8):990-2. http://dx.doi.org/10.1016/S0954-6111(03)00128-8

50. Cevrioglu AS, Fidan F, Unlu M, et al. The effects of hormone therapy on pulmonary function tests in postmenopausal women. Maturitas 2004;49(3):221-7. http://dx.doi.org/10.1016/j.maturitas.2004.01.009

51. Chen Y, Breithaupt K, Muhajarine N. Occurrence of chronic obstructive pulmonary disease among Canadians and sex-related risk factors. J Clin Epidemiol 2000;53(7):755-61. http://dx.doi.org/10.1016/S0895-4356(99)00211-5

52. De Torres JP, Campo A, Casanova C, Aguirre-Jaime A, Zulueta J. Gender and chronic obstructive pulmonary disease in high-risk smokers. Respiration 2006;73(3):306-10. http://dx.doi.org/10.1159/000090051

53. Lokke A, Lange $P$, Scharling $H$, Fabricius $P$, Vestbo J. Developing COPD: a 25 year follow up study of the general population. Thorax 2006;61(11):935-9. http://dx.doi.org/10.1136/thx.2006.062802

54. Schirnhofer L, Lamprecht B, Vollmer WM, et al. COPD prevalence in Salzburg, Austria: results from the Burden of Obstructive Lung Disease (BOLD) study. Chest 2007;131(1):29-36. http://dx.doi.org/10.1378/chest.06-0365

55. Halbert RJ, Natoli JL, Gano A, Badamgarav E, Buist AS, Mannino DM. Global burden of COPD: systematic review and meta-analysis. Eur Respir J 2006;28(3):523-32. http://dx.doi.org/10.1183/09031936.06.00124605

56. Di Marco F, Verga M, Reggente $M$, et al. Anxiety and depression in COPD patients: the roles of gender and disease severity. Respir Med 2006;100(10):1767-74. http://dx.doi.org/10.1016/j.rmed.2006.01.026

57. Dales RE, Mehdizadeh A, Aaron SD, Vandemheen KL, Clinch J. Sex differences in the clinical presentation and management of airflow obstruction. Eur Respir $J$ 2006;28(2):319-22. http://dx.doi.org/10.1183/09031936.06.00138105

58. Watson L, Vestbo J, Postma DS, et al. Gender differences in the management and experience of chronic obstructive pulmonary disease. Respir Med 2004;98(12):1207-13. http://dx.doi.org/10.1016/j.rmed.2004.05.004

59. Martinez FJ, Curtis JL, Sciurba F, et al. Sex differences in severe pulmonary emphysema. Am J Respir Crit Care Med 2007;176(3):243-52. http://dx.doi.org/10.1164/rccm.200606-8280C

60. Watson L, Schouten JP, Lofdahl CG, Pride NB, Laitinen LA, Postma DS; European Respiratory Society Study on Chronic Obstructive Pulmonary Disease. Predictors of 
COPD symptoms: does the sex of the patient matter? Eur Respir J 2006;28(2):31118. http://dx.doi.org/10.1183/09031936.06.00055805

61. Rodriguez-Gonzalez Moro M, Izquierdo JL, Anton E, de Lucas P, Martin A; MUVICE Study Group. Health-related quality of life in outpatient women with COPD in daily practice: the MUVICE Spanish study. Respir Med 2009;103(9):1303-12. http://dx.doi.org/10.1016/j.rmed.2009.04.002

62. Fan VS, Ramsey SD, Giardino ND, et al. Sex, depression, and risk of hospitalization and mortality in chronic obstructive pulmonary disease. Arch Intern Med 2007;167(21):2345-53. http://dx.doi.org/10.1001/archinte.167.21.2345

63. Katsura H, Yamada K, Wakabayashi R, Kida K. Gender-associated differences in dyspnoea and health-related quality of life in patients with chronic obstructive pulmonary disease. Respirology 2007;12(3):427-32. http://dx.doi.org/10.1111/ j.1440-1843.2007.01075.x

64. Van Ede L. Yzermans CJ, Brouwer HJ. Prevalence of depression in patients with chronic obstructive pulmonary disease: a systematic review. Thorax 1999;54(8):688-92. http://dx.doi.org/10.1136/thx.54.8.688

65. Andrade L, Caraveo-Anduaga JJ, Berglund $P$, et al. The epidemiology of major depressive episodes: results from the International Consortium of Psychiatric Epidemiology (ICPE) Surveys. Int J Methods Psychiatr Res 2003;12(1):3-21. http://dx.doi.org/10.1002/mpr.138

66. Chavannes NH, Huibers MJ, Schermer TR, et al. Associations of depressive symptoms with gender, body mass index and dyspnea in primary care COPD patients. Fam Pract 2005;22(6):604-07. http://dx.doi.org/10.1093/fampra/cmi056

67. Laurin C, Lavoie KL, Bacon SL, et al. Sex differences in the prevalence of psychiatric disorders and psychological distress in patients with COPD. Chest 2007;132(1):148-55. http://dx.doi.org/10.1378/chest.07-0134

68. Ninot $G$, Fortes $M$, Poulain $M$, et al. Gender difference in coping strategies among patients enrolled in an inpatient rehabilitation program. Heart Lung 2006;35(2):130-6. http://dx.doi.org/10.1016/j.hrtlng.2005.09.004

69. Kennedy TC, Proudfoot SP, Franklin WA, et al. Cytopathological analysis of sputum in patients with airflow obstruction and significant smoking histories. Cancer Res 1996;56(20):4673-8.

70. Risch HA, Howe GR, Jain M, Burch JD, Holowaty EJ, Miller AB. Are female smokers at higher risk for lung cancer than male smokers? A case-control analysis by histologic type. Am J Epidemiol 1993;138(5):281-93.

71. Osann KE, Anton-Culver H, Kurosaki T, Taylor T. Sex differences in lung-cancer risk associated with cigarette smoking. Int J Cancer 1993;54(1):44-8. http://dx.doi.org/10.1002/ijc.2910540108

72. Zang EA, Wynder EL. Differences in lung cancer risk between men and women: examination of the evidence. J Natl Cancer Inst 1996;88(3-4):183-92. http://dx.doi.org/10.1093/jnci/88.3-4.183

73. Henschke Cl, Yip R, Miettinen OS. Women's susceptibility to tobacco carcinogens and survival after diagnosis of lung cancer. JAMA 2006;296(2):180-4. http://dx.doi.org/10.1001/jama.296.2.180

74. Ahmed LA, Schirmer H, Bjornerem A, et al. The gender- and age-specific 10-year and lifetime absolute fracture risk in Tromso, Norway. Eur J Epidemiol 2009;24(8):441-8. http://dx.doi.org/10.1007/s10654-009-9353-8

75. Camp PG, Coxson HO, Levy RD, et al. Sex differences in emphysema and airway disease in smokers. Chest 2009;136(6):1480-8. http://dx.doi.org/ 10.1378/chest.09-0676

76. Sverzellati N, Calabro E, Randi G, et al. Sex differences in emphysema phenotype in smokers without airflow obstruction. Eur Respir J 2009;33(6):1320-8. http://dx.doi.org/10.1183/09031936.00109808

77. Grydeland TB, Dirksen A, Coxson HO, et al. Quantitative computed tomography: emphysema and airway wall thickness by sex, age and smoking. Eur Respir $J$ 2009;34(4):858-65. http://dx.doi.org/10.1183/09031936.00167908

78. Laitinen $\mathrm{T}$, Hodgson $\mathrm{U}$, Kupiainen $\mathrm{H}$, et al. Real-world clinical data identifies gender-related profiles in chronic obstructive pulmonary disease. COPD 2009;6(4):256-62. http://dx.doi.org/10.1080/15412550903051799

79. Chapman KR, Tashkin DP, Pye DJ. Gender bias in the diagnosis of COPD. Chest
2001;119(6):1691-5. http://dx.doi.org/10.1378/chest.119.6.1691

80. Miravitlles M, de la Roza C, Naberan K, et al. Attitudes toward the diagnosis of chronic obstructive pulmonary disease in primary care. [Spanish] Arch Bronconeumo/ 2006;42(1):3-8. http://dx.doi.org/10.1016/S1579-2129(06)60106-7

81. Han MK, Kim MG, Mardon R, et al. Spirometry utilization for COPD: how do we measure up? Chest 2007;132(2):403-09. http://dx.doi.org/10.1378/chest.06-2846

82. Cydulka RK, Rowe BH, Clark S, Emerman CL, Rimm AR, Camargo CA Jr. Gender differences in emergency department patients with chronic obstructive pulmonary disease exacerbations. Acad Emerg Med 2005;12(12):1173-9. http://dx.doi.org/10.1111/j.1553-2712.2005.tb01493.x

83. Bjornson W, Rand C, Connett JE, et al. Gender differences in smoking cessation after 3 years in the Lung Health Study. Am J Public Health 1995;85(2):223-30. http://dx.doi.org/10.2105/AJPH.85.2.223

84. Bohadana A, Nilsson F, Rasmussen T, Martinet $Y$. Gender differences in quit rates following smoking cessation with combination nicotine therapy: influence of baseline smoking behavior. Nicotine Tob Res 2003;5(1):111-16. http://dx.doi.org/10.1080/1462220021000060482

85. Schmitz JM. Smoking cessation in women with cardiac risk. Am J Med Sci 2003;326(4):192-6. http://dx.doi.org/10.1097/00000441-200310000-00008

86. Ussher $M H$, Taylor $A H$, West $R$, McEwen R. Does exercise aid smoking cessation? A systematic review. Addiction 2000;95(2):199-208. http://dx.doi.org/10.1046/j.1360-0443.2000.9521996.x

87. Jorenby DE, Leischow SJ, Nides MA, et al. A controlled trial of sustained-release bupriopion, a nicotine patch, or both smoking cessation. N Engl J Med 1999;340(9):685-91. http://dx.doi.org/10.1056/NEJM199903043400903

88. Jorenby DE, Hays JT, Rigotti NA, et al. Efficacy of varenicline, an alpha4beta2 nicotinic acetylcholine receptor partial agonist, vs placebo or sustained-release bupropion for smoking cessation: a randomized controlled trial. JAMA 2006;296(1):56-63. http://dx.doi.org/10.1001/jama.296.1.56

89. Gonzales D, Rennard SI, Nides M, et al. Varenicline, an alpha4beta2 nicotinic acetylcholine receptor partial agonist, vs sustained-release bupropion and placebo for smoking cessation: a randomized controlled trial. JAMA 2006;296(1):47-55. http://dx.doi.org/10.1001/jama.296.1.47

90. Perkins KA. Nicotine discrimination in men and women. Pharmacol Biochem Behav 1999;64(2):295-9. http://dx.doi.org/10.1016/S0091-3057(99)00085-4

91. Wetter DW, Kenford SL, Smith SS, Fiore MC, Jorenby DE, Baker TB. Gender differences in smoking cessation. J Consult Clin Psychol 1999;67(4):555-62. http://dx.doi.org/10.1037/0022-006X.67.4.555

92. Benowitz NL, Lessov-Schlaggar CN, Swan GE, Jacob P 3rd. Female sex and oral contraceptive use accelerate nicotine metabolism. Clin Pharmacol Ther 2006;79(5):480-8. http://dx.doi.org/10.1016/j.clpt.2006.01.008

93. Celli BR, MacNee W, ATS/ERS Task Force. Standards for the diagnosis and treatment of patients with COPD: a summary of the ATS/ERS position paper. Eur Respir J 2004;23(6):932-46. http://dx.doi.org/10.1183/09031936.04.00014304

94. Lima JJ, Mohamed MH, Self TH, Eberle JV, Johnson JA. Importance of beta(2)adrenergic receptor genotype, gender and race on albuterol-evoked bronchodilation in asthmatics. Pulm Pharmacol Ther 2000;13(3):127-34. http://dx.doi.org/10.1006/pupt.2000.0239

95. Tashkin D, Celli B, Kesten S, Lystig T, Decramer M. Effect of tiotropium in men and women with COPD: results of the 4-year UPLIFT trial. Respir Med 2010;104(10):1495-504. http://dx.doi.org/10.1016/j.rmed.2010.03.033

96. Vestbo J, Soriano JB, Anderson JA, Calverley P, Pauwels R, Jones P; TRISTAN Study Group. Gender does not influence the response to the combination of salmeterol and fluticasone propionate in COPD. Respir Med 2004;98(11):1045-50. http://dx.doi.org/10.1016/j.rmed.2004.03.017

97. Calverley PM, Anderson JA, Celli B, et al. Salmeterol and fluticasone propionate and survival in chronic obstructive pulmonary disease. $N$ Engl J Med 2007;356(8):775-89. http://dx.doi.org/10.1056/NEJMoa063070

98. Celli BR, Thomas NE, Anderson JA, et al. Effect of pharmacotherapy on rate of decline of lung function in chronic obstructive pulmonary disease: results from the 
TORCH study. Am J Respir Crit Care Med 2008;178(4):332-8. http://dx.doi.org/10.1164/rccm.200712-18690C

99. Tashkin DP, Celli B, Senn S, et al. A 4-year trial of tiotropium in chronic obstructive pulmonary disease. N Engl J Med 2008;359(15):1543-54. http://dx.doi.org/ 10.1056/NEJMoa0805800

100. Tashkin DP, Rennard SI, Martin P, et al. Efficacy and safety of budesonide and formoterol in one pressurized metered-dose inhaler in patients with moderate to very severe chronic obstructive pulmonary disease: results of a 6-month randomized clinical trial. Drugs 2008;68(14):1975-2000. http://dx.doi.org/ 10.2165/00003495-200868140-00004

101. Rennard SI, Tashkin DP, McElhattan J, et al. Efficacy and tolerability of budesonide/formoterol in one hydrofluoroalkane pressurized metered-dose inhaler in patients with chronic obstructive pulmonary disease: a results from a 1-year randomized controlled clinical trial. Drugs 2009;69(5):549-65. http://dx.doi.org/10.2165/00003495-200969050-00004

102. Lizak MK, Nash E, Zakliczynski M, Sliwka J, Knapik Pm, Zembala M. Additional spirometry criteria predict postoeperative complications after coronary after bypass grafting (CABG) independently of concomitant chronic obstructive pulmonary disease: when is off-pump CABG more beneficial? Pol Arch Med Wewn 2009;119(9):550-7.

103. Haave E, Skumlien S, Hyland ME. Gender considerations in pulmonary rehabilitation. J Cardiopulm Rehabil Prev 2008;28(3):215-19.
104. Foy CG, Rejeski WJ, Berry MJ, Zacarro D, Woodard CM. Gender moderates the effects of exercise therapy on health-related quality of life among COPD patients. Chest 2001;119(1):70-6. http://dx.doi.org/10.1378/chest.119.1.70

105. Franklin KA, Gustafson T, Ranstam J, Strom K. Survival and future need of longterm oxygen therapy for chronic obstructive pulmonary disease - gender differences. Respir Med 2007;101(7):1506-11. http://dx.doi.org/10.1016/ j.rmed.2007.01.009

106. Machado MC, Krishnan JA, Buist SA, et al. Sex differences in survival of oxygendependent patients with chronic obstructive pulmonary disease. Am J Respir Crit Care Med 2006;174(5):524-9. http://dx.doi.org/10.1164/rccm.200507-10570C

107. Centers for Disease Control and Prevention. Chronic obstructive pulmonary disease - United States, 2000-2005. Morb Mortal Wkly Rep 2008;57(45):1229-32.

108. Cote CG, Pinto-Plata VM, Marin JM, Nekach H, Dordelly L, Celli BR. The modified BODE index: validation with mortality in COPD. Eur Respir J 2008;32(5):1269-74. http://dx.doi.org/10.1183/09031936.00138507

109. Lange P, Nyboe, Appleyard M, Jensen G, Schnor. Relation of ventilatory impairment and of chronic mucus hypersecretion to mortality from obstructive lung disease and from all causes. Thorax 1990;45(8):579-85. http://dx.doi.org/ 10.1136/thx.45.8.579

110. Nilsson S, Carstensen JM, Pershagen G. Mortality among male and female smokers in Sweden: a 33 year follow up. J Epidemiol Community Health 2001;55(11):82530. http://dx.doi.org/10.1136/jech.55.11.825

\section{COMMENTARY}

\section{Sex and gender differences in COPD: challenging the stereotypes}

\section{*Audrey DunnGalvina}

${ }^{a}$ Department of Early Years and Childhood Studies, Department of Paediatrics and Child Health, University College Cork, Ireland.

The relationship of sex and gender to health and disease is complex, and varies across an individual's lifespan. This has implications for (potentially) differing patterns of disease prevalence, different degrees of severity, and different patterns of mortality and morbidity between men and women. ${ }^{1,2}$

Sex denotes the differences attributed to biological origins alone, while gender refers to the social and cultural influences that lead to differences between women and men. ${ }^{3}$

Chronic obstructive pulmonary disease (COPD) is an increasing cause of morbidity and mortality worldwide. Although COPD has historically been considered a disease of male smokers, it now clearly impacts on both sexes. ${ }^{4}$ As Ohar, Fromer, \& Donohue point out in this helpful review, ${ }^{5}$ the paradigm of COPD is changing from a male-predominant two-category disorder, to a disorder characterised by multiple co-morbidities with a growing female prevalence.
Careful evaluation, and a raised awareness of the possibility that sex or gender (or both) may influence COPD susceptibility and progression, is of critical importance for two main reasons: firstly, because the potential future impact of the disease may have been underestimated; ${ }^{4}$ and secondly, because the condition is primarily diagnosed and managed by general practitioners (GPs). GPs are as vulnerable as their patients to sex and gender stereotypes, and this can impact on information processing and decision-making.

This review ${ }^{5}$ highlights key research areas in COPD where sex and gender stereotypes can be challenged - including disease susceptibility, symptoms, treatment, prognosis, and diagnosis. Although biological determinants of sex and age differences in airway behaviour (dimensional, immunological, and hormonal) have been known for many years, ${ }^{6}$ there are still major gaps in our knowledge about COPD phenotypes. In particular, little is known about the mechanisms and

\footnotetext{
* Corresponding author: Dr Audrey DunnGalvin, Department of Early Years and Childhood Studies, Department of Paediatrics and Child Health, College Rd, University College Cork, Cork City, Ireland. Tel: 00353-21-4902684 E-mail: A.DunnGalvin@ucc.ie
} 